\title{
収穫時期がブロッコリーの呼吸速度，成分含量および 品質に及ぼす影響
}

\author{
池田浩暢 ${ }^{18}$ ・藤瀬朋子*2 ・宮城一菜*2 \\ 茨木俊行 ${ }^{* 1}$.太田英明 ${ }^{* 2}$ \\ * 1 福岡県農業総合試験場食品流通部 \\ * 2 中村学園大学栄養科学部
}

\section{Effects of Harvest Season on Respiration Rate, Chemical Composition and Quality Stability of Broccoli (Brassica oleracea L. italica)}

\author{
IKedA Hironobu*1§, Fujise Tomoko*2, MiYagi Kazuna*2, \\ IBARAKI Toshiyuki ${ }^{* 1}$ and OHTA Hideaki*2 \\ * 1 Fukuoka Agricultural Research Center, 587, Yoshiki, Chikushino-shi, Fukuoka 818-8549 \\ * 2 Department of Nutritional Sciences, Nakamura Gakuen University \\ 5-7-1, Befu, Johnan-ku, Fukuoka 814-0198
}

To study the preservative property of various shredded vegetables treated by steam heating, cabbage, cucumber, The respiration rate, chemical composition in terms of reduced ascorbic acid and total soluble sugar, and quality stability of broccoli harvested in autumn (November), winter (January) and spring (April) were investigated during storage at room temperature or $15^{\circ} \mathrm{C}$. A nearly second-order regression equation $\left(\mathrm{Y}=\mathrm{a}+\mathrm{b}^{*} \mathrm{~T}+\mathrm{c}^{*} \mathrm{~T}^{2}\right)$ with a high relative coefficient $(\mathrm{R}=0.989-0.996)$ was established for the respiration rate $\left(\mathrm{mg} \mathrm{CO} \cdot \mathrm{kg}^{-1} \cdot \mathrm{hr}^{-1}\right)(\mathrm{Y})$ and temperature $\left({ }^{\circ} \mathrm{C}\right)(\mathrm{T})$ of broccoli. At the sametemperature, broccoli harvested in winter showed a higher respiration rate than that harvested in autumn. Broccoli harvested in winter had two times as much total soluble sugar content as that harvested in autumn or spring. For broccoli harvested in autumn and stored at room temperature, its reduced ascorbic acid, total soluble sugar and chlorophyll contents decreased markedly with floret yellowing. These indicate that broccoli harvested in autumn and stored at room temperature does not retain good quality. The reduced ascorbic acid and total soluble sugar contents of broccoli harvested in winter remained unchanged for 6 days, suggesting that the broccoli retains good quality during storage at room temperature. Similarly, broccoli harvested in winter and stored at $15^{\circ} \mathrm{C}$ showed had much better quality stability than broccoli harvested in the other seasons. For the same harvestseason, the quality of broccoli was successfully maintained during storage atlow temperature. Moreover, correlations among the respiration rate, chemical composition and quality stability of broccoli were observed, that is the lower the respiration rate, the higher the reduced ascorbic acid and totalsoluble sugar contents and the higher the quality stability.

(Received Jun. 7, 2007 ; Accepted Oct. 17, 2007)

Key words : harvest season, broccoli, respiration rate, chemical composition, quality stability 収穫時期, ブロッコリー, 呼吸速度, 成分含量, 品質

野菜の品質や鮮度保持期間に影響を及ぼす栽培条件と しては，品種や系統などの遺伝的因子，水分や肥料管理 などの栽培技術および気温や収穫時期などの栽培環境が
あげられる。遺伝的因子としては, ブロッコリー1やキ ヤベツ2)では，同じ時期に収穫した場合でも品種によっ て呼吸速度や成分含量が異なることが報告されている。

* 1 T 818-8549 福岡県筑紫野市大字吉木587

* 2 \% 814-0198 福岡県福岡市城南区別府 5-7-1

$\S$ 連絡先 (A corresponding author) E-mail :ikeda-h1630@pref.fukuoka.lg.jp 
また，栽培技術として，トマト ${ }^{3,4)}$ では，潅水量を制限 すると糖含量やアスコルビン酸含量が増加し, 鮮度保持 期間が延びることが，アスパラガズでは，施肥量を通 常の 2 倍与えると呼吸速度やエチレン生成量が低く, 鮮 度低下が抑制されることが示されている。栽培環境とし て，ホウレンソウ ${ }^{6}$ では，冬期収穫したものでは夏期収 穫したものに比べて糖含量やアスコルビン酸含量だけで なく呼吸速度も高くなることが，キャべツでは，冬期 収穫のものでは他の時期に収穫したものに比べて糖含量 が高くなることが報告されている。しかし，収穫時期に よって成分含量や呼吸速度が異なるにもかかわらず，鮮 度保持期間との関係を検討した研究例は，葉ネギで報告 されているにすぎない ${ }^{8)}$

そこで，本章ではブロッコリーについて収穫時期別の 呼吸速度や全糖含量, アスコルビン酸含量など成分含量 を測定するとともに，鮮度保持期間との関係を検討した。

\section{実験方法}

\section{1 . 収穫時期がブロッコリーの呼吸速度に及ぼす影響}

11月20日（秋期），1月30日（冬期）および4月15日 (春期）に，福岡県二丈町で収穫したブロッコリー (Brassica oleracea L. italica, サイズ：2L) を供試し た。品種は，秋期，冬期および春期それぞれエルデ，グ リーンハットおよびグリーンビューティーであった。花 蕾先端部からの長さを $15 \mathrm{~cm}$ に調製した後，9株ずつを 慣行の普通段ボール容器に縦詰めし, 福岡県農業総合試 験場（福岡県筑紫野市, 以下, 試験場と略す）に搬入し た。ブロッコリー 3 株を内容積14.1 1 のアクリル樹脂製 チャンバーに入れ, 内径が $3 \mathrm{~mm}$ のガラス製パイプおよび $4 \mathrm{~mm}$ のアリル樹脂製パイプ (内容積; 約 $5 \mathrm{~m} \ell$ ) でエア ポンプ（テクノ高㭇社製; SPP- $3 \mathrm{EBS}$, 流量7.5 $\mathrm{l}$ ・ $\left.\mathrm{min}^{-1}\right)$ と連結させた。 $0 \sim 40^{\circ} \mathrm{C}$ に設定した恒温庫内に 一夜放置し，ブロッコリーの品温を安定させた。測定時 は，エアポンプをアクリル樹脂製パイプで連結させ，千 ヤンバー内の空気を密閉式で循環させた。1時間ごとに チャンバー内のガスを採取し，ガスクロマトグラフ（島 津製作所製; GC- 8 A, 検出器; TCD, カラム; ポラパ

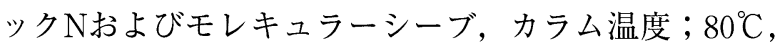
キャリアガス；へリウム）を用いて，二酸化炭素および 酸素濃度を測定した。単位時間当たりに変化するこれら のガス濃度から二酸化炭素排出速度（以下, 呼吸速度と 略す）を算出した。また，測定後直ちにブロッコリーの 葉茎部に温度計（安立計器社製；AP-210）の針状セン サーを差し込み，品温を測定した。

\section{2. 収穫時期がブロッコリーの成分含量および鮮度に及 ぼす影響}

10月31日（秋期），1月25日（冬期）および 4 月 8 日 （春期）に, 福岡県二丈町で収穫したブロッコリーを供 試した。品種は，秋期，冬期および春期それぞれエルデ， グリーンハットおよびグリーンビューティーであった。
9 株ずつを厚さ $0.02 \mathrm{~mm}$ の低密度ポリエチレンフィルム袋 を内装した普通段ボール容器（以下，PE内装段ボール 容器と略す）に縦詰めした後，上部をハンカチ折り込み 包装した。これを試験場に搬入し，室温および $15^{\circ} \mathrm{C}$ の恒 温庫内に静置した。以後 1 日おきに容器内の酸素および 二酸化炭素濃度を前述のTCDガスクロマトグラフで測 定した後, 各 1 箱を開封した。還元型アスコルビン酸含 量 (以下, アスコルビン酸含量と略す), 全糖含量, 総 クロロフィル含量を測定した。各成分分析は，1 試験区 当たり 8 反復行った。保存中の平均室温は, 秋期で $17.3^{\circ} \mathrm{C}$, 冬期で $4.5^{\circ} \mathrm{C}$ ，春期で $9.0^{\circ} \mathrm{C}$ であった。

（1）アスコルビン酸含量の測定ブロッコリーの花 蕾を先端から約 $3 \mathrm{~mm}$ 切り出し, このうち約 $5 \mathrm{~g}$ を測定に 用いた。アスコルビン酸の測定は, 須田ら ${ }^{9}$ の方法に準 じて行った。すなわち，花蕾に $5 \%$ メタリン酸を加え磨 砕抽出 L, 遠心分離後 $(3,000 \mathrm{rpm}, 10 \mathrm{~min}$, 室温) 得 られた上澄を，さらに東洋濾紙No. 5Bでろ過した後， 25 $\mathrm{m} \ell に$ 定容したものを試料溶液とした。試料溶液の $0.5 \mathrm{~m} \ell$ を採り,これにpH7.000.2Mリン酸緩衝液 $5 \mathrm{~m} \ell, 1 \mathrm{mg} \cdot$ $\mathrm{m} \ell^{-1}$ サザ由来のペルオキシダーゼ（和光純薬工業製； $100 \mathrm{U} / \mathrm{mg} ） 0.2 \mathrm{~m} \ell, 50 \mathrm{mM}$ 過酸化水素水 $0.02 \mathrm{~m} \ell$ を加えて 振とうした。 $37^{\circ} \mathrm{C}$ の恒温水槽内漕で20分間保持した 後, $265 \mathrm{~nm}$ の波長で吸光度を測定した。過酸化水素水を 加えないものを対照として, 吸光度の差を求めた。既知 濃度の標準アスコルビン酸を同様に処理した場合の吸光 度から検量線を作製し，アスコルビン酸含量を算出した。

（2）全糖含量の測定 アスコルビン酸含量と同様に 花蕾の先端部分約 $5 \mathrm{~g}$ を用いた。これを $80 \%$ エタノール で $100^{\circ} \mathrm{C}$ で10分間処理し，糖を抽出した。 $100 \mathrm{~m} \ell に$ 定容後， 抽出液の最終濃度が $0.1 \mathrm{~N}$ となるように塩酸を加え, 沸 騰水中で20分間加水分解し，還元糖液を得た。水酸化ナ

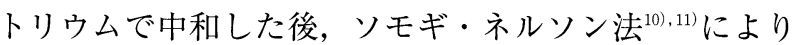
測定した。

（３）総クロロフィル含量の測定 全糖の抽出時に得 られたエタノール溶液を試料溶液とし, 舆座ら ${ }^{12)}$ の方法 に従って定量した。すなわち, 東洋濾紙No.2でろ過し た後 $100 \mathrm{~m} \ell に$ 定容し，665および $649 \mathrm{~nm}$ の波長で吸光度を 測定し，総クロロフィル含量を算出した。

\section{結 果}

\section{1. 収穫時期および品温がブロッコリーの呼吸速度に及 ぼす影響}

収穫時期別のブロッコリーの品温と呼吸速度の関係を Fig. 1に示した。品温が $10^{\circ} \mathrm{C}$ 以下では, 収穫時期が呼吸 速度に及ぼす影響はほとんど認められなかった。しかし， 品温が $10^{\circ} \mathrm{C}$ 以上になると収穫時期による差が認められ, 品温が高くなるほどその差は大きくなった。同じ品温で あれば, ブロッコリーの呼吸速度は秋期収穫のもので最 も低く, 春期収穫のものは秋期収穫のものよりやや高く, 冬期収穫のもので最も高くなった。 


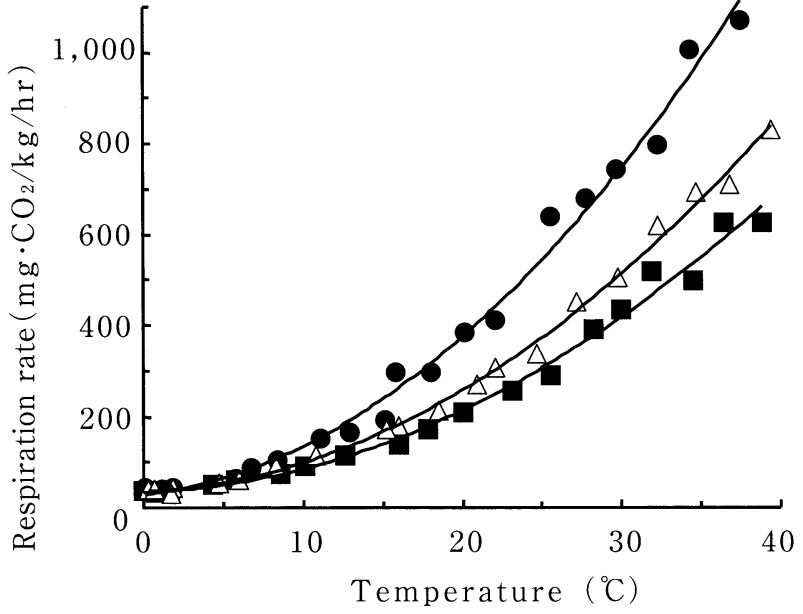

Fig. 1 Relationship between storage temperature and respiration rate of broccoli

: harvested in winter (January)

$\triangle:$ harvested in spring (April)

a : harvested in autumn (November)

収穫時期別のブロッコリーの品温と呼吸速度の近似式 をTable 1 に示した。本研究において測定した品温域で は，いずれの時期に収穫したブロッコリーでも品温と呼 吸速度の関係は二次式で近似することができ，相関係数 は0.989〜0.996と高かった。

\section{2. 収穫時期がブロッコリーの成分含量および鮮度に及} ぼす影響

（1）室温に保存した場合の品質変化収穫時期別の 出荷容器内の酸素濃度および二酸化炭素濃度の経時変化 をTable 2 に示した。出荷容器内のガス濃度は，秋期収 穫のもので最も低酸素・高二酸化炭素状態となり, 酸素

Table 1 Regression equation $\left(\mathrm{Y}=\mathrm{a}+\mathrm{b}^{*} \mathrm{~T}+\mathrm{c}^{*} \mathrm{~T}^{2}\right)$ analysis of temperature of broccoli $(\mathrm{T})$ and respiration $\operatorname{rate}(\mathrm{Y})$

\begin{tabular}{ccccc}
\hline Season & $\mathrm{a}$ & $\mathrm{b}$ & $\mathrm{c}$ & $\mathrm{R}$ \\
\hline Autumn & 34.569 & 1.214 & 0.385 & 0.989 \\
Winter & 28.254 & 3.995 & 0.665 & 0.990 \\
Spring & 36.152 & 1.421 & 0.482 & 0.996 \\
\hline
\end{tabular}

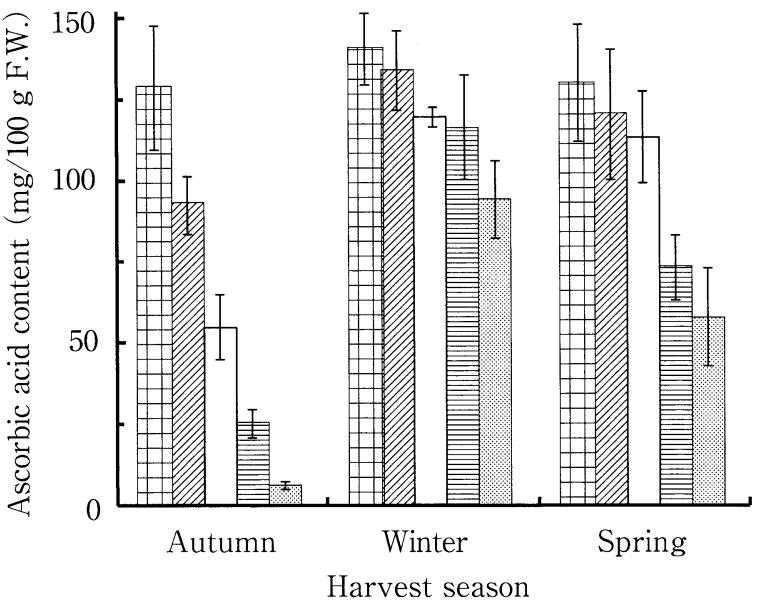

Fig. 2 Effects of harvest season on ascorbic acid content of broccoli during storage at room temperature

$$
\begin{aligned}
& \boxplus: 0 \text { day }: 2 \text { days in storage } \square: 4 \text { days in storage } \\
& \text { 更: } 6 \text { days in storage } \square: 8 \text { days in storage } \\
& \text { Vertical bars in the graph show standard deviation }(n=8)
\end{aligned}
$$

濃度は7.8〜 $10.7 \%$ ，二酸化炭素濃度は7.6〜 $10.2 \%$ あ った。これは，秋期収穫のものでは冬期収穫や春期収穫 のものに比べて室温が高く推移したことで，呼吸速度が 高かったためと考えられる。また, 冬期収穫のもので最 も高酸素・低二酸化炭素状態となり, 酸素濃度は14.0 $15.2 \%$ ，二酸化炭素濃度は4.9〜 7.0\%であった。これは， 冬期収穫のものでは秋期収穫や春期収穫のものに比べて 室温が低く推移したことで，呼吸速度が抑制されたため と考えられる。開箱時の異臭は, 出荷容器内の酸素濃度 が最も低く推移した秋期収穫のものにおいても，保存 8 日後まで認められなかった。

収穫時期がアスコルビン酸含量に及ぼす影響をFig. 2 に示した。アスコルビン酸含量は，いずれの収穫時期に おいても時間の経過とともに減少した。特に，秋期収穫 のものでは 2 日後から, 春期のものでは 6 日後から急激 に減少し，8 日後にはそれぞれ試験開始時の $5 \%$ ，40\% となった。一方，冬期収穫のものでは，その減少割合は 他の時期に収穫したものに比べて緩やかで，8 日後にお いても試験開始時の $67 \%$ を保持していた。

\begin{tabular}{|c|c|c|c|c|c|c|c|c|c|}
\hline \multirow{3}{*}{$\begin{array}{c}\text { Harvest } \\
\text { Season }\end{array}$} & \multirow{3}{*}{ Gas } & \multicolumn{4}{|c|}{ Room Temperature } & \multicolumn{4}{|c|}{$15^{\circ} \mathrm{C}$} \\
\hline & & \multicolumn{4}{|c|}{ Days in storage } & \multicolumn{4}{|c|}{ Days in storage } \\
\hline & & 2 & 4 & 6 & 8 & 2 & 4 & 6 & 8 \\
\hline \multirow[t]{2}{*}{ Autumn } & $\mathrm{CO}_{2}$ & 7.6 & 8.6 & 10.2 & 8.0 & 4.7 & 6.1 & 4.1 & 4.7 \\
\hline & $\mathrm{O}_{2}$ & 10.7 & 9.1 & 7.8 & 9.5 & 12.1 & 10.8 & 12.9 & 13.2 \\
\hline \multirow[t]{2}{*}{ Winter } & $\mathrm{CO}_{2}$ & 5.8 & 7.0 & 6.4 & 4.9 & 15.2 & 16.4 & 14.3 & 12.7 \\
\hline & $\mathrm{O}_{2}$ & 15.0 & 14.0 & 14.8 & 15.2 & 5.4 & 4.5 & 5.7 & 6.5 \\
\hline \multirow[t]{2}{*}{ Spring } & $\mathrm{CO}_{2}$ & 7.5 & 5.8 & 6.2 & 6.5 & 8.5 & 9.0 & 9.5 & 9.0 \\
\hline & $\mathrm{O}_{2}$ & 10.9 & 12.3 & 12.1 & 11.6 & 8.9 & 8.6 & 8.4 & 7.2 \\
\hline
\end{tabular}

Table 2 Effects of harvest season of broccoli on carbon dioxide and oxygen concentrations (\%) in film bags stored at room temperature and $15^{\circ} \mathrm{C}$

The mean room temperature for 8 days in autumn was $17.3^{\circ} \mathrm{C}$, that in winter was $4.5^{\circ} \mathrm{C}$, and that in spring was $9.0^{\circ} \mathrm{C}$ 
収穫時期が全糖含量に及ぼす影響をFig. 3に示した。 試験開始時の全糖含量は，秋期収穫や春期収穫のもので はそれぞれ1.0，1.2\%であったが，冬期収穫のものでは $2.2 \%$ と他の時期に収穫したものに比べて約 $1 \%$ 高い 值を示した。全糖含量は，いずれの収穫時期においても 時間の経過とともに減少した。特に，秋期収穫のもので は2 日後から急激に減少し，8 日後には試験開始時の $18 \%$ となった。一方，春期収穫や冬期収穫のものではそ の減少割合は秋期収穫したものに比べて緩やかで，8日 後においてもそれぞれ試験開始時の64，83\%を保持して いた。

収穫時期が総クロロフィル含量に及ぼす影響をFig. 4 に示した。総クロロフィル含量は，秋期収穫のものでは

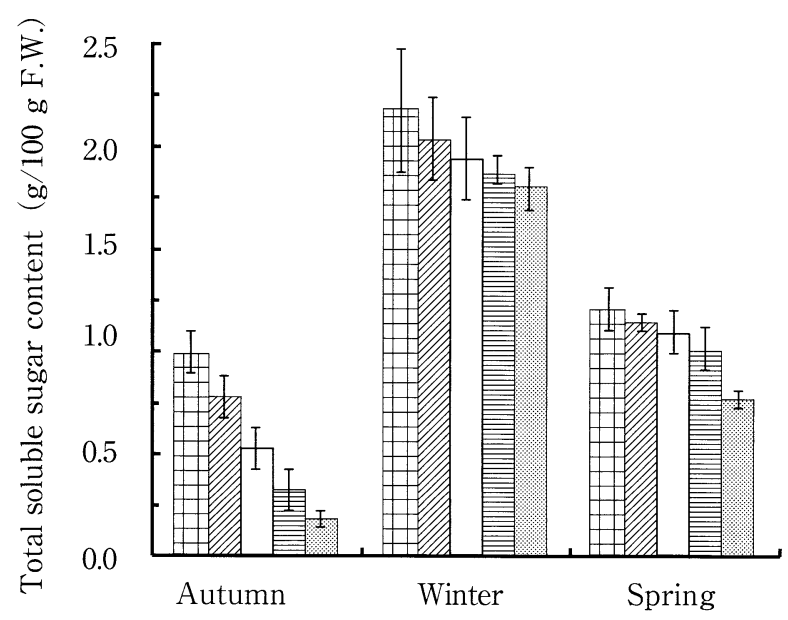

Harvest season

Fig. 3 Effects of harvest season on total soluble sugar content of broccoli during storage at room temperature

Symbols are the same as those shown in Fig. 2.

Vertical bars in the graph show standard deviation $(n=8)$.

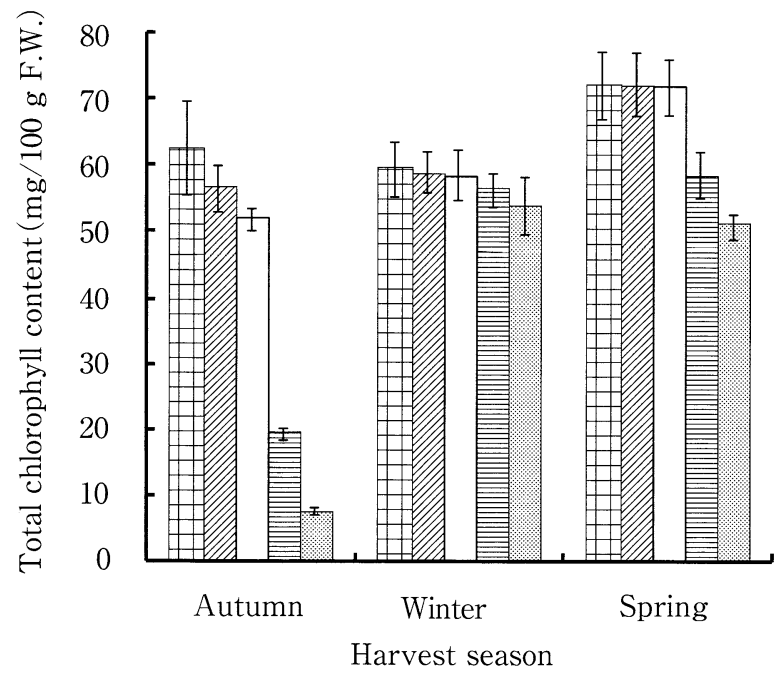

Fig. 4 Effects of harvest season on total chlorophyll content of broccoli during storage at room temperature

Symbols are the same as those shown in Fig. 2.

Vertical bars in the graph show standard deviation $(n=8)$.
2 日後から, 春期収穫のものでは 6 日後から減少し, 8 日後にはそれぞれ試験開始時の $12 \% ％ 70 \%$ となった。 方，冬期収穫のものではその減少割合は他の時期に収穫 したものに比べて緩やかで，8日後においても試験開始 時の $90 \%$ 以上を保持していた。

これらのことから, 室温に保存した場合, 秋期収穫の ものでは保存 2 日後からアスコルビン酸含量, 全糖含量 および総クロロフィル含量は減少し，8 日後における成 分含量は他の時期に収穫したものに比べて最も低くなっ た。春期収穫のものでは，成分含量は秋期収穫のものよ り保持されたが，冬期収穫のものより減少した。冬期収 穫のものでは，全糖含量やアスコルビン酸含量は時間の 経過とともに徐々に減少したが, 総クロロフィル含量は 8 日後まで試験開始時の含量を保持していた。

（2） $15^{\circ} \mathrm{C}$ に保存した場合の品質変化収穫時期別の 出荷容器内の酸素濃度および二酸化炭素濃度の経時変化 をTable 2 に示した。出荷容器内のガス濃度は, 室温に 保存した場合とは逆の傾向が認められた。すなわち，冬 期収穫のもので最も低酸素・高二酸化炭素状態となり, 酸素濃度は4.5〜6.5\%，二酸化炭素濃度は $13.7 \sim 16.4 \%$ であった。また，秋期収穫のもので最も高酸素・低二酸 化炭素状態となり, 酸素濃度は10.8～ $13.2 \%$ ，二酸化炭 素濃度は4.1〜6.1\%であった。これは，冬期収穫のもの では収穫時の気温と保存温度である $15^{\circ} \mathrm{C}$ との温度差が最 も大きくなったために，収穫時に比べて呼吸速度が急激 に上昇し, 酸素の消費および二酸化炭素の蓄積が他の時 期のものより大きくなったためと考えられる。開箱時の 異臭は, 出荷容器内の酸素濃度が最も低く推移した冬期 収穫のものにおいても，8日後まで認められなかった。

収穫時期がアスコルビン酸含量に及ぼす影響をFig. 5 に示した。アスコルビン酸含量は, 秋期収穫のものでは 室温に保存した場合とほぼ同様に推移し，8 日後には試

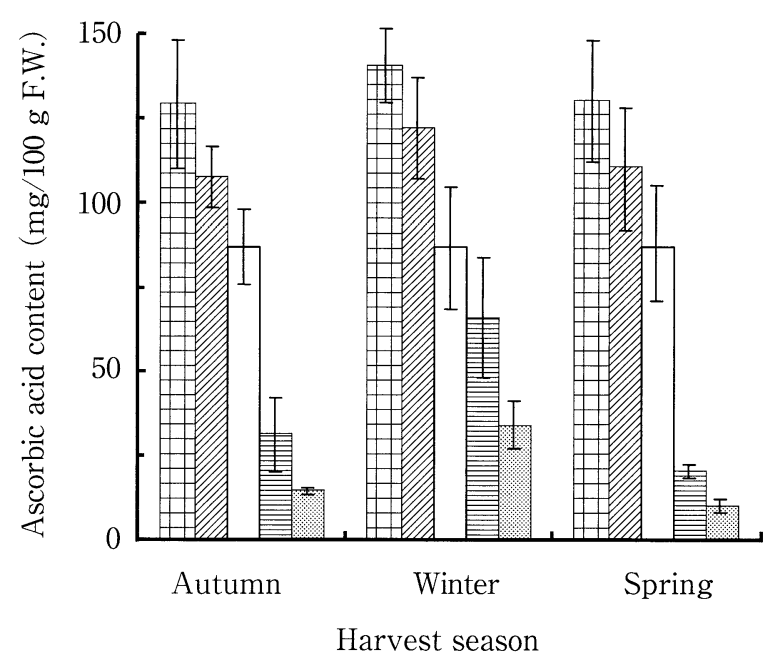

Fig. 5 Effects of harvest season on ascorbic acid content of broccoli during storage at $15{ }^{\circ} \mathrm{C}$

Symbols are the same as those shown in Fig. 2.

Vertical bars in the graph show standard deviation $(n=8)$. 
験開始時の $11 \%$ となった。一方, 春期収穫や冬期収穫の ものでは室温に保存した場合よりも急激に減少し，8日 後にはそれぞれ試験開始時の $8 \% ， 25 \%$ となった。

収穫時期が全糖含量に及ほす影響をFig. 6に示した。 全糖含量は, 秋期収穫のものでは室温に保存した場合よ りも緩やかに減少し，8 日後には試験開始時の $40 \%$ とな った。一方, 春期収穫や冬期収穫のものでは室温に保存 した場合よりも急激に減少し，8日後にはそれぞれ試験 開始時の $12 \% ， 68 \%$ となった。

収穫時期が総クロロフィル含量に及ぼす影響をFig. 7 に示した。総クロロフィル含量は, 秋期収穫のものでは 室温に保存した場合より緩やかに減少し，8 日後には試 験開始時の $20 \%$ となった。一方, 春期収穫や冬期収穫の

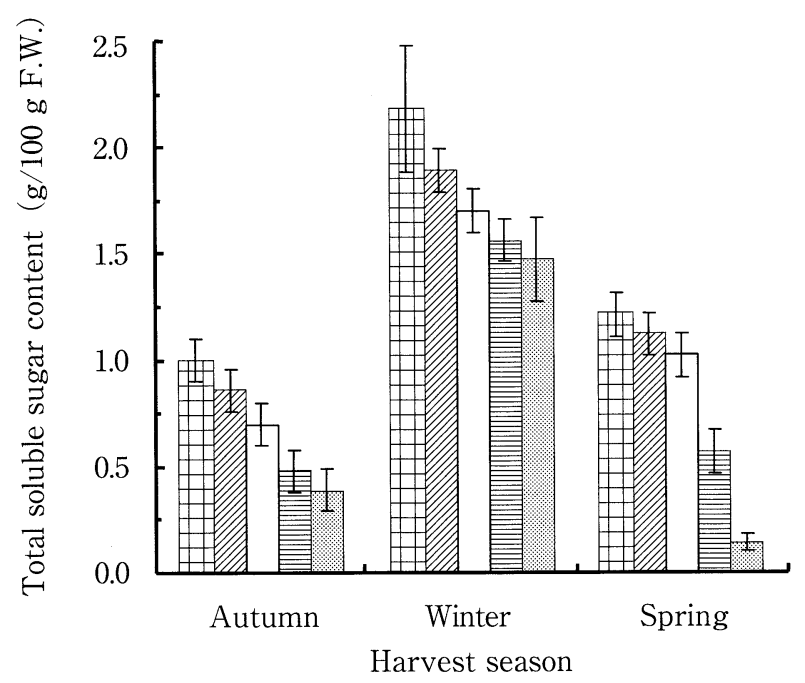

Fig. 6 Effects of harvest season on total soluble sugar content of broccoli during storage at $15^{\circ} \mathrm{C}$

Symbols are the same as those shown in Fig. 2. Vertical bars in the graph show standard deviation $(n=8)$.

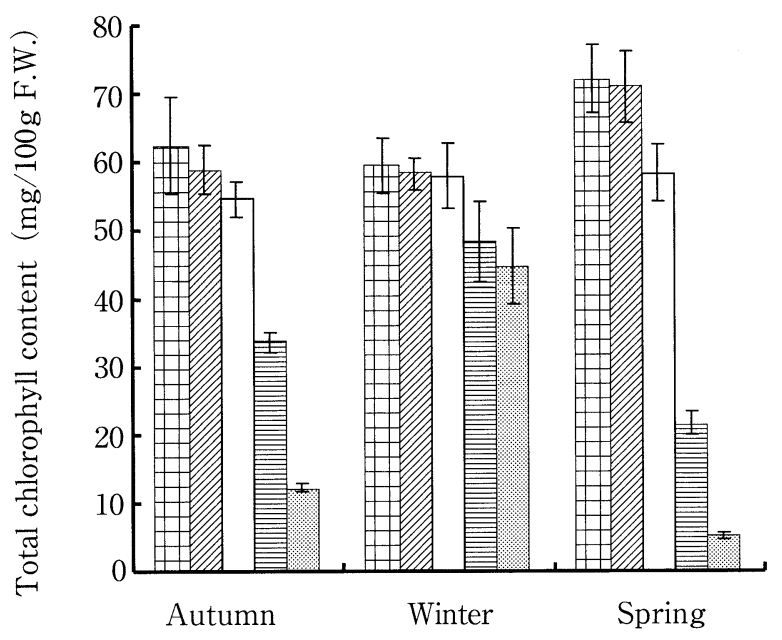

Harvest season

Fig. 7 Effects of harvest season on total chlorophyll content of broccoli during storage at $15^{\circ} \mathrm{C}$

Symbols are the same as those shown in Fig. 2.

Vertical bars in the graph show standard deviation $(n=8)$.
ものでは, 室温に保存した場合よりも急激に減少し, 8 日後にはそれぞれ試験開始時の10\%，76\%まで減少した。

これらのことから， $15^{\circ} \mathrm{C} に$ 保存した場合, 春期収穫の ものでは保存 2 日後からアスコルビン酸含量, 全糖含量 および総クロロフィル含量は減少し，8日後における成 分含量は他の時期に収穫したものに比べて最も低くなっ た。秋期収穫のものでは, アスコルビン酸含量など成分 含量は春期収穫のものより保持されたが, 冬期収穫のも のより減少した。冬期収穫のものでは, 成分含量は時間 の経過とともに徐々に減少したが，その含量は試験期間 を通じて他の時期に収穫したものより高く推移した。

\section{考察}

収穫時期と青果物の成分含量の関倸については，ホウ レンソウ ${ }^{13}$ やトマト ${ }^{14)}$ では, 収穫時期によって全糖, ア スコルビン酸抒よびクロロフィル含量が変動すると報告 されている。本研究においても, ブロッコリーの全糖含 量は，秋期および春期収穫のものでは $1.0 \%, 1.2 \%$ あ゙ ったが, 冬期収穫のものでは $2.2 \%$ と他の時期に比べて

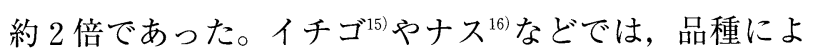
って成分含量は変動することが報告されているが，ブロ ッコリーでは収穫時期が同じであれば品種による全糖含 量の差は最大 $10 \%$ 程度であると示している1”。このため, ブロッコリーに打いても, 収穫時期によって全糖含量は 変動することが明らかになった。これに対し，アスコル ビン酸含量やクロロフィル含量については, 収穫時期に よる変動はほとんど認められなかった。同様の傾向はチ

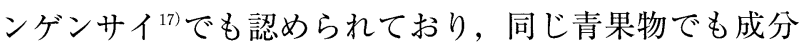
の種類によって収穫時期の影響が異なると考えられた。

青果物の呼吸速度と品温の関係については, これまで アレニウスの式 ${ }^{13)}$ や指数関数 ${ }^{19}$, 二次式 ${ }^{201}$ などで表すこ とができると報告されている。しかし，葉ネギ20ににおい て, 流通過程で想定される $0 \sim 35^{\circ} \mathrm{C}$ の温度域では二次式 で最も相関が高くなり，アレニウスの式や指数関数では 二次式に表した場合に比べて相関は低いことを示してい る。このため, 本研究においてもブロッコリーの呼吸速 度と品温の関係を二次式で表したところ, 高い相関が得 られた。Table 1 から得られた近似式をもとに，まず収 穫時における収穫時期別のブロッコリーの呼吸速度を推 測した。収穫前 1 週間の平均気温は, 秋期で $11.4^{\circ} \mathrm{C}$, 冬 期で $3.4^{\circ} \mathrm{C}$, 春期で $9.0^{\circ} \mathrm{C}$ であった。収穫時のブロッコリ 一の品温が気温とほぼ同じであると仮定すると, 収穫時 期別の呼吸速度は, 秋期収穫では $98.5 \mathrm{mgCO}_{2} \cdot \mathrm{kg}^{-1} \mathrm{hr}^{-1}$, 冬期収穫では $49.5 \mathrm{mgCO}_{2} \cdot \mathrm{kg}^{-1} \mathrm{hr}^{-1}$, 春期収穫では 66.3 $\mathrm{mgCO}_{2} \cdot \mathrm{kg}^{-1} \mathrm{hr}^{-1}$ となり, 秋期収穫の呼吸速度は, 冬期 収穫の約 2.0 倍であると考えられる。次に, 同じ品温に おける収穫時期別のブロッコリーの呼吸速度を推測した。 同じ品温におけるブロッコリーの呼吸速度は, 収穫時と は逆に冬期収穫のもので最も高く, 秋期収穫のもので最 も低くなった。品温が $15^{\circ} \mathrm{C}$ の場合, 収穫時期別の呼吸速 
度は冬期収穫では $237.8 \mathrm{mgCO}_{2} \cdot \mathrm{kg}^{-1} \mathrm{hr}^{-1}$, 秋期収穫では $139.5 \mathrm{mgCO}_{2} \cdot \mathrm{kg}^{-1} \mathrm{hr}^{-1}$ となり, 冬期収穫の呼吸速度は秋 期収穫に比べ約 1.7 倍であった。また，品温が $30^{\circ} \mathrm{C}$ の場 合，冬期収穫では $746.7 \mathrm{mgCO}_{2} \cdot \mathrm{kg}^{-1} \mathrm{hr}^{-1}$ ，秋期収穫では $417.7 \mathrm{mgCO}_{2} \cdot \mathrm{kg}^{-1} \mathrm{hr}^{-1}$ となり，冬期収穫は秋期収穫の約 1.8倍であった。したがって，収穫時期がブロッコリー の呼吸速度に及ぼす影響は, 品温が高くなるほど大きく なることが明らかになった。

このように, 品温が同じでも収穫時期によって呼吸速 度が異なることは，葉ネギ ${ }^{00}$ やホウレンソウ ${ }^{13)} て ゙$ 報告さ れている。これには，品温変動が影響していると考えら れる。キュウリやナス ${ }^{21}$ などでは, 品温が上昇すると呼 吸速度は一時的に過上昇状態となり, 品温変動が大きい ほど呼吸速度の上昇程度は大きくなるとともに，過上昇 状態から安定状態に達するまで長時間を要すると報告し ている。また，品温が低下する場合では呼吸速度は速や かに低下し, 上昇時のような特異的な現象は認められな いとしている。このため，品温上昇は品温降下に比べて， 野菜の生理活性に及ぼす影響が大きいと考えられる。

本研究では, 測定温度が高くなるほど, 冬期収穫のブ ロッコリーでは秋期収穫や春期収穫のものよりも生育時 との品温変動が大きくなるため, 収穫時期による呼吸速 度の差が大きくなったと考えられる。一方，測定温度が 低い場合では, 品温降下が呼吸速度に及ぼす影響は小さ いため，収穫時期による差は小さかったと考えられる。 また，収穫時期が同じでも品種によって呼吸速度が異な ることがブロッコリーで報告されている1”。このため, 同じ品種を収穫時期毎に供試することが望ましいが，1 品種の収穫可能期間は $2 \sim 4$ 週間程度と短いため, 年間 を通じて同じ品種を用いることは困難である。これらの ことから，ブロッコリーでは品温変動や品種によって， 収穫時期別の呼吸速度が異なると考えられる。

野菜の鮮度保持に影響を及ぼす要因の一つに, 呼吸速 度があげられる。呼吸速度と青果物の鮮度保持の関係に ついては, 呼吸速度が高い青果物ほど腐敗しやすいと報 告している ${ }^{22)}$ 。ホウレンソウでは, 栽培方法の違いから 生じる呼吸速度の大小によって貯蔵性は影響を受けると 示している ${ }^{6)}$ 。葉市ギ ${ }^{(8)}$ やアスパラガス ${ }^{23)}$ では, 呼吸速度 が高いほど鮮度保持期間は短いことを報告している。本 研究において, ブロッコリーの呼吸速度は収穫時期によ って異なり，それぞれの収穫時の温度であれば, 秋期収 穫で最も高く，冬期収穫で最も低くなった。これに対し， 同じ温度であれは冬期収穫が最も高く，秋期収穫で最も 低くなった。しかし，ブロッコリーの成分含量や外観品 質は，保存温度にかかわらず冬期収穫のもので最も高く 保持されていた。このため, ブロッコリーにおいては, 呼吸速度と成分含量や外観品質の保持との関係は一致せ ず，葉ネギやアスパラガスのように呼吸速度が低いほど 成分含量や外観品質が高く保たれることは認められなか った。
この原因として, 呼吸の基質である全糖含量と野菜の 鮮度保持との関係が考えられる。ホウレンソウ ${ }^{6}$ では, 栽培方法の違いによって全糖含量は大きく異なるものの 呼吸速度も大きく異なるため, 保存中の全糖含量はほぼ 同様となり，貯蔵性には影響がないと報告している。ま た, 葉ネギ8では, 収穫時期の違いによって呼吸速度は 大きく異なるが，いずれの収穫時期においても全糖含量 の減少は少ないため, 全糖含量よりも呼吸速度のほうが 鮮度保持期間に影響を及ぼすことを示している。これに 対し, サヤインゲン ${ }^{24)} レ タ ス{ }^{25)}$ では, 全糖含量の多少 が貯蔵性を左右すると報告している。また，キャべッ ${ }^{26)}$ では, 糖含量が高い品種ほど保存可能日数が長くなるこ とから, 全糖含量の減少までの日数が長いほど貯蔵性が 高いと推測している。本研究において，ブロッコリーの 全糖含量は, 冬期収穫のものでは秋期収穫や春期収穫の ものに比べて約 2 倍多くなった。一方，ブロッコリーの 呼吸速度は, 収穫時期の違いによって大きく異なるが, 全糖含量の減少はいずれの収穫時期においてもほぼ同じ であった。このため, $15^{\circ} \mathrm{C} に$ 保存した場合, 冬期収穫し たブロッコリーの呼吸速度が秋期収穫や春期収穫したも のより高かったにもかかわらず，冬期収穫のものが秋期 収穫や春期収穫したものに比べて, 成分含量や外観品質 は高く保たれた。これらのことから，ブロッコリーでは 呼吸速度だけでなく, 全糖含量も鮮度保持に影響を及ぼ すものと考えられる。

また, 他の成分含量については, アスコルビン酸含量 は全糖含量とほほ同様に減少したが, クロロフィル含量 はやや遅れて減少した。キャベッやレタスでは呼吸基 質が消耗して正常な生理機能を果たせなくなった後，腐 敗が始まるとしている。ホウレンソウ ${ }^{6)}$ では，まず呼吸 基質である糖が減少し, その後アスコルビン酸, 最後に クロロフィル含量が減少すると報告している。今後は, 特に鮮度が低下しやすい秋期および春期収穫のブロッコ リーでは, 全糖含量など成分含量の多い品種の育成が望 まれる。

\section{要 約}

ブロッコリーの収穫時期ごとの品質と鮮度保持期間を 明らかにするために，11月（秋期），1月（冬期）およ び 4 月（春期）に収穫したものの温度別の呼吸速度を調 査し, 室温および $15^{\circ} \mathrm{C}$ の恒温庫内に出荷容器ごとに保存 し，鮮度保持に及ぼす影響を調査した。

(1)いずれの時期に収穫したブロッコリーにおいても， 品温と呼吸速度の関係は二次式に近似できた。同じ 品温であれば, 呼吸速度は冬期収穫のもので最も高 く, 秋期収穫のもので最も低かった。これとは逆に, 収穫時における呼吸速度は秋期のもので最も高く, 冬期のもので最も低かった。

(2) 室温に保存した場合, 秋期収穫のブロッコリーで はアスコルビン酸含量が早くから低下し，総クロロ 
フィル含量の低下も他の時期に収穫したものに比べ て速く, 鮮度保持期間が短くなった。冬期収穫のも のでは成分含量の保持に優れ, 外観品質の低下も緩 やかで，鮮度保持期間も長かった。

(3) $15^{\circ} \mathrm{C}$ に保存した場合, 秋期収穫や春期収穫のブロ ッコリーではアスコルビン酸含量が早くから低下し, 総クロロフィル含量の低下も冬期収穫したものに比 べて速く, 鮮度保持期間が短くなった。冬期収穫の ものでは成分含量の保持に優れ, 外観品質の低下も 緩やかで，鮮度保持期間も長かった。

(4) ブロッコリーの鮮度保持は呼吸速度よりも全糖含 量と良く一致し, 全糖含量が高いほど鮮度保持期間 が長かった。

\section{文献}

1) 松本通夫・松田弘毅・山下昭道・有福一郎：9 月ど り作型ブロッコリーの二酸化炭素排出量と鮮度保持, 鳥取県食品加工研究所研究報告，33，38４2（1995）

2 ) 矢野昌充・西條了康・太田保夫：イソチオシアネー 卜類によるカットキャベツの褐変防止とエチレン生成 阻害, 園学雑, 55, 194～198（1986）

3 ）渡邊幸雄・米山昌美・嶋田典司：ホウレンソウの糖, ビタミンCおよびシュウ酸含量に及ぼす水ストレス処 理の影響，土肥誌，58，427〜432（1987）

4 ) 図師一文・松添直隆: 土壤水分制限が大果系トマト のビタミンC, 糖, 有機酸, アミノ酸およびカロチン 含量に与える影響, 園学雑, 67，927～933（1998）

5 ) 山県真人 - 中野啓三 - 金森哲夫：暖地転作畑におけ るグリーンアスパラガスの弱茎生産および品質・貯蔵 性に及ぼす施肥条件の影響, 四国農試報, $52,1 \sim 12$ (1989)

6 ） 日坂弘行：ホウレンソウ貯蔵中における呼吸量, 糖 含量の変化と外観の劣化との関係, 日食工誌, 36, 956 〜963（1989）

7 ）矢野昌充 - 伊藤 洋 - 速水昭彦 - 小濱節雄 : 野菜の 品質に及ほす栽培条件の影響に関する研究（1）キャ ベッ及びニンジンの糖組成・含量, 野菜茶試報告, A- 8 , 53〜68（1981）

8 ）茨木俊行 - 池田浩暢 - 太田英明 : 収穫時期が葉ネギ の呼吸速度, 化学成分および鮮度保持に及ぼす影響,

日食保蔵誌，23，77～82（1997）

9 ）須田郁夫 - 西場洋一・古田 収：酵素反応を利用し たビタミンC定量法の改良, 九州農業研究, 57, 41 (1995)

10) PALEG, L. G. : Citric acid interference in the estimation of reducing sugars with alkaline copper reagents, Anal. Chem., 31, 1902 1904 (1959)

11) Somogyi, M. : Notes on sygar determination, $J$. Biol. Chem., 195, 19 23 (1952)

12）與座宏一 - 野方洋一 - 武田裕子 - 子役丸孝俊 - 太田
英明：ポリエチレン積層段ボール箱包装が常温貯蔵中 におけるブロッコリーの鮮度保持に及ぼす効果, 日食 保蔵誌，19，107～110（1993）

13）日坂弘行：葉菜類の䝪蔵温度と品質に関する研究, 千葉農試特別報告，20，3～30（1992）

14）篠原 温・鈴木芳夫 ・渋谷正夫：施設トマトの栽培 法, 栽培時期及び品種と果実のアスコルビン酸含量, 園学雑，51，338～343（1982）

15）曽根一純・望月龍也・野口裕司：イチゴ果実におけ るビタミンC含量の品種間差異および収穫時期による 変動特性，園学雑，68，1007～1014（1999）

16）阿部一博・黒岡 浩：数種栽培品種のナス果実のア スコルビン酸含量の相違と低温障害発生程度の関連, 日食保蔵誌，24，237～242（1998）

17）池羽智子 - 貝塚隆史 - 石井 貴: チンゲンサイのビ 夕ミンC, 糖, 硝酸含量に及ぼす品種, 栽培条件の影 響，茨城県農総七園研研報，13，17～23（2005）

18) Song, Y., KIM, H. K. and YAM K. L.: Respiration rate of Blueberry in Modified Atmosphere at Various Temperatures, J. Amer. Soc. Hort. Sci., 117, 925 929 (1992)

19) Beaudry, R. M., Cameron, A. C., Shirazi, A. and Dostal-Lange, D. L. : Modified Atmosphere Packaging of Blueberry Fruits : Effect of Temperature on Package $\mathrm{O}_{2}$ and $\mathrm{CO}_{2}$, J. Amer. Soc. Hort. Sci., 117, 436 441 (1992)

20）茨木俊行・池田浩暢・打田 宏・太田英明：フィル 厶包装および出荷容器が葉ネギの鮮度に及ぼす影響, 日食保蔵誌，21，67～72（1995）

21）森 健・門間 充・三輪 操：青果物の呼吸量に 及ぼす温度の影響, 昭和 58 年秋季園芸学会講演要旨 集，438〜439（1983）

22) KADER, A. A. : Respiration and gas exchange of vegetables (Weichmann, J., ed. : Postharvest physiology of vegetables), Food Sci. Technol., 25 43 (1987)

23) Brash, D. W., Chris, M. C., Sandy, W. and Bruce, L. B. : Shelf-life of stored asparagus is strongly related to postharvest respiratory activity, Postharvest. Biol. Technol., 5, 77 81 (1995)

24) Watada, A. E. and Morris, L. L. : Post-harvest behavior of snap bean tivars, J. Amer. Soc. Hort. Sci., 89, 375 380 (1967)

25）矢野昌充・速水昭彦：結球性野菜の貯蔵性改善に関 する研究II, レタスの収穫後における生理変化の特性 と貯蔵性の関係について, 野菜試験場報告, A- 4, 89 〜 101 (1978)

26）西條了康：野菜の鮮度保持技術と施設（1）, 農業 及び園芸，63，1071〜1076（1988）

(平成19年 6 月 7 日受付, 平成 19 年 10 月 17 日受理) 